\title{
Mobile Multimedia Evaluation: Development of Stop Drugs Tutorial
}

https://doi.org/10.3991/ijim.v13i05.9436

\author{
Hadi Sutopo ${ }^{(凶)}$, Ridha Sefina Samosir, Jullend Gatc \\ Institut Teknologi dan Bisnis Kalbis, Jakarta, Indonesia \\ hadi.sutopo@kalbis.ac.id
}

\begin{abstract}
This research is intended to evaluate the development of mobile multimedia based stop drug tutorial. This tutorial as a campaign to stop drugs, that should encourage people's ability to integrate all information on mobile application. The tutorial focuses on how people understand about drugs and what to do if someone is drugs addicted. Stopping drug tutorial is created using ADDIE instructional development method, and during the developing stage, it is conducted using Multimedia Development Life Cycle according to Luther. Subjects of the research are experts in education, visual communication and information technology in the preliminary testing. Evaluation was conducted using the analytic descriptive method on mobile multimedia evaluation method, and interpreted in a narrative way based on the research findings. The evaluation of mobile multimedia application uses combination of multimedia evaluation that is used by educationalist with ISO 9126 that was used by software developer. The research findings show that mobile multimedia stop drugs application can be used with minor revision.
\end{abstract}

Keywords-Drugs; evaluation; instruction; mobile multimedia; tutorial

\section{Introduction}

Learning is a necessity in life, since his/her birth till the ends, to be able to achieve his/her independence and to adapt to various environmental changes [1]. Nowadays, due to globalization and proliferation of technology, mobile applications are used for variety purposes, including learning, information, campaign, advertisement, etc. Using together multimedia elements in mobile application such as images and animations that are equipped with sound, video clips, and text, will be able to give clear meaning to those who need it. Vaughan stated that multimedia can bring radical changes in the learning process, from passive student learning to active student learning [2]. So multimedia can be used to inform young people that drugs harm their health.

There is also the fact that smoking, drinking alcohol or taking drugs are seen as acts of rebellion. Young people know that these potentially harmful substances are bad for them which make them even more attractive. They understand that it is risky and frowned upon by adults, but it can give impact an excitement, comfort, confi- 
dence, and bravery. Young people do not care the addiction and even damage their health in the long time [3].

This study aims to develop a mobile multimedia application particularly to campaign or inform that drugs harm their health and developing damage young generation, and then evaluate it whether achieves the objective and useful for young people. This application can be used by people especially young generation to understand how dangerous and harmful is. By studying through running the mobile application, it is expected to enhance people avoid the drugs environment and the instruction if someone is in a situation involved to drugs abuse.

Prior research showed that the criminal offenses of heroin and crack-cocaine users were examined. In summary, little evidence found that drugs could cause increasing the violent crime. "The National Criminal Victimization Survey perceived more than one fourth of violent criminal assailants to be under the influence of alcohol, less than $10 \%$ of these assailants were reported by victims to be under the influence of illicit drugs". Most of the drug-users used to be violent economic criminal in order to support their expensive habit. [4]

\subsection{Drugs}

World Health Organization (WHO) defines drug as a chemical substance of synthetic, semi synthetic or natural origin intended for diagnostic, therapeutic or palliative use or for modifying physiological functions of human and animal. Drug impacts directly influence the economic and social aspects of a country and physically to a human body. These drug addicted people are from all strata of the society. It shows that the country is going to be transformed into potential users of drugs with the rapid increase in the number of addicts. [5]

After the pre-mature stage abusers become seriously addicted. They have to take it every day, after a certain period. In maximum of cases it is taken from evening to night time. For that, they are busy all day long in collecting the expenditure of drug. They need much more money for it and sometimes they turn against the law. Many discontinue their education after failing to concentrate on any kind of discipline. After mature stage most of the abusers stay on the verge of decaying. It means gradually their lives crumble. Gradually after a few hours they have to take it, otherwise their body system stops. In that situation the abuser loses human characteristics and behaves like a monster.

The body relaxes and the mind feels fresh after taking drugs. If an addict cannot take it, peevish temperament occurs and he doesn't wish to work or even talk. He or she feels fever, headache, itches in his body and sometimes vomiting also occurs. Most of the students of this group are frustrated and unhappy in their study life. Drug addiction has grabbed not only the youth but it has grabbed the social leaders also. In the present situation, we need to strengthen family and social values and religious ethics in order to maintain a stable and drug-free society. [5] 


\subsection{Media}

An instructional tutorial as an information is a series of instructional messages that share a single idea and theme which make up an integrated communication. Instructional information utilizes diverse media channels over a particular time frame and are often mandated to be rationally defined. The information theme is the central message that will be conveyed in the important activities and is the main focus of tutorial information as it sets the motif for the series of multifarious individual messages and other tutorial communications that will be used. The tutorial themes are usually produced with the objective of being used for a significant period but many of them are temporal due to factors like being not effective. [6]

There are many types of media, which can be selected to create a multimedia application. Although multimedia is used frequently to refer to CBT, the media is always considered using a blended solution consisting of whatever media are required. One of the types of media is using either internet or intranet to distribute instruction over wide area networks. Through advancements in digital communication channels, using mobile devices tends increasing in the last few years. The reason why people like to use mobile device is the advantage of using it while they are doing an activity anywhere and anytime.[7]

\section{Method}

There are two kinds of methods that are used in this research. The first method is developing mobile application and then the second one uses mobile multimedia evaluation method.

\subsection{Developing mobile multimedia}

Designing the tutorial was required to gain a good product, so that the learning process became more effective and efficient. Different model of instructional design including ADDIE (Analyze, Design, Develop, Implement, and Evaluate), Dick and Carey, Hannifen and Peck, Knirk and Gustafson, Jerrold Kemp, and Gerlach \& Ely have developed [8]. Although many instructional design models exist, they all contain five generic phases. These are analysis of learning and performance problems, design, development, implementation, and evaluation [9]. ADDIE model can be described in Fig. 1 as follows:

- Analyze: The objective of this paper is defined, for drugs impact information, content of information, audience and infrastructure

- Design: The interface design and algorithm that will be used in the tutorial are developed. Storyboard and navigation structure can be used to describe the project

- Develop [10]: During this step, developing product uses Multimedia Development Life Cycle according to Luther [11]. The overall of the project is built, the drugs impact information is assembled using Adobe Flash with ActionScript programming. During the testing, the application is run and checked to confirm that it per- 
forms exactly what the author has intended. At the first phase, the system is tested to fix all the functions of application work well. After the functional testing, the application must be run on variety mobile devices

- Implement: During this step, the application is reproduced and delivered to audience for their use on their mobile devices. The distributed application file should be run on mobile devices

- Evaluate: The application must be evaluated whether it can increase knowledge for people.

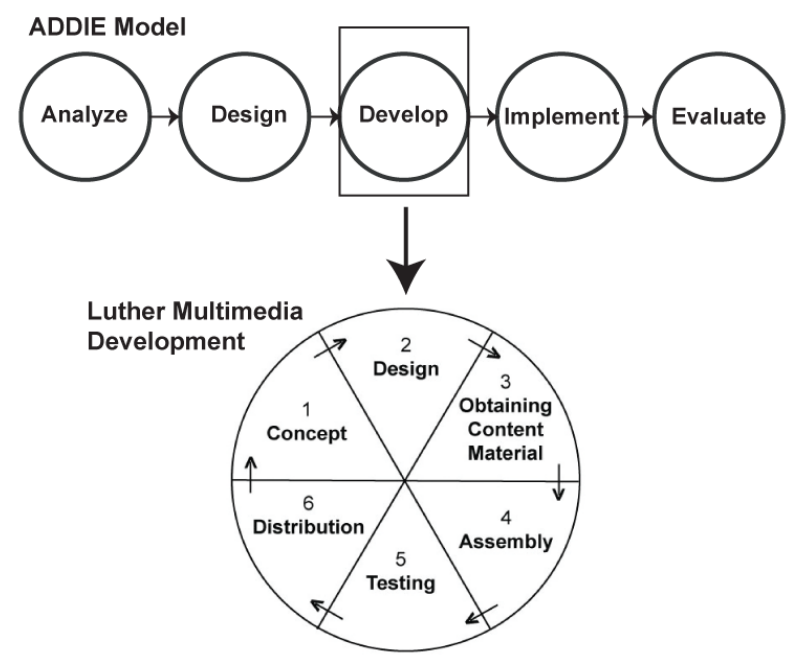

Fig. 1. Research method combining ADDIE model and Multimedia Development Life Cycle according to Luther

Authoring is somewhat like making a feature film, a movie, and there are many steps to the process. Developing multimedia based application as an interactive multimedia instructions, consists of six stages in Fig. 1 as follows: Concept, Design, Obtaining Content Material, Assembly, Testing, and Distribution [11]. During the Design stage, the activity is developing a storyboard and navigation structure. The activity gives storyboard as an overview based on quite abstract design, and breaks down navigation structure that is usually embedded in traditional approaches to course delivery.

\subsection{Mobile multimedia evaluation}

Evaluating mobile tutorial systems comes from two directions, the educationalists and the software developers. The International Organization for Standardization (ISO) was founded in 1946 in order to facilitate international trade, international coordination and unification of industrial standards by providing a single set of standards that would be recognized and respected. ISO 9126 was originally developed in 1991 to 
provide a framework for evaluating software quality [12]. This is in fact one of its strengths as it is more adaptable and can be used across many systems, including mobile-learning systems. The original model defined six product characteristics that are used for evaluation can be seen in Fig. 2 and Table 1.

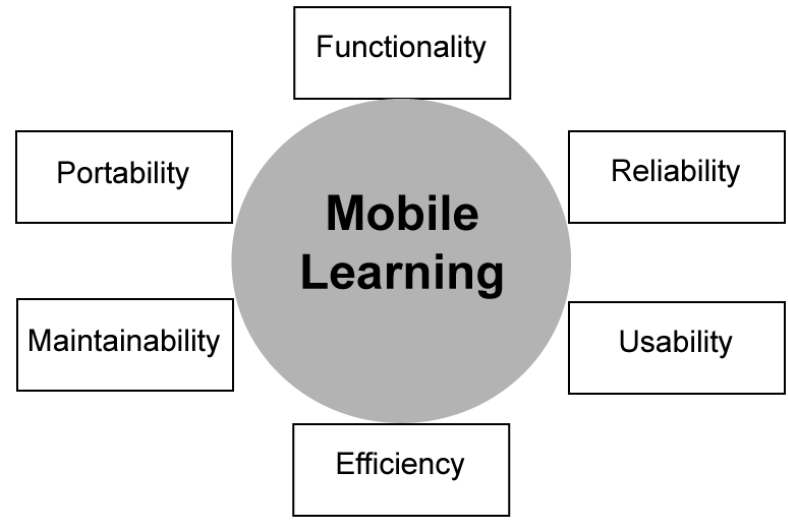

Fig. 2. Six product characteristics of ISO 9126 as a framework for evaluating software quality

Table 1. Evaluation variables of ISO 9126

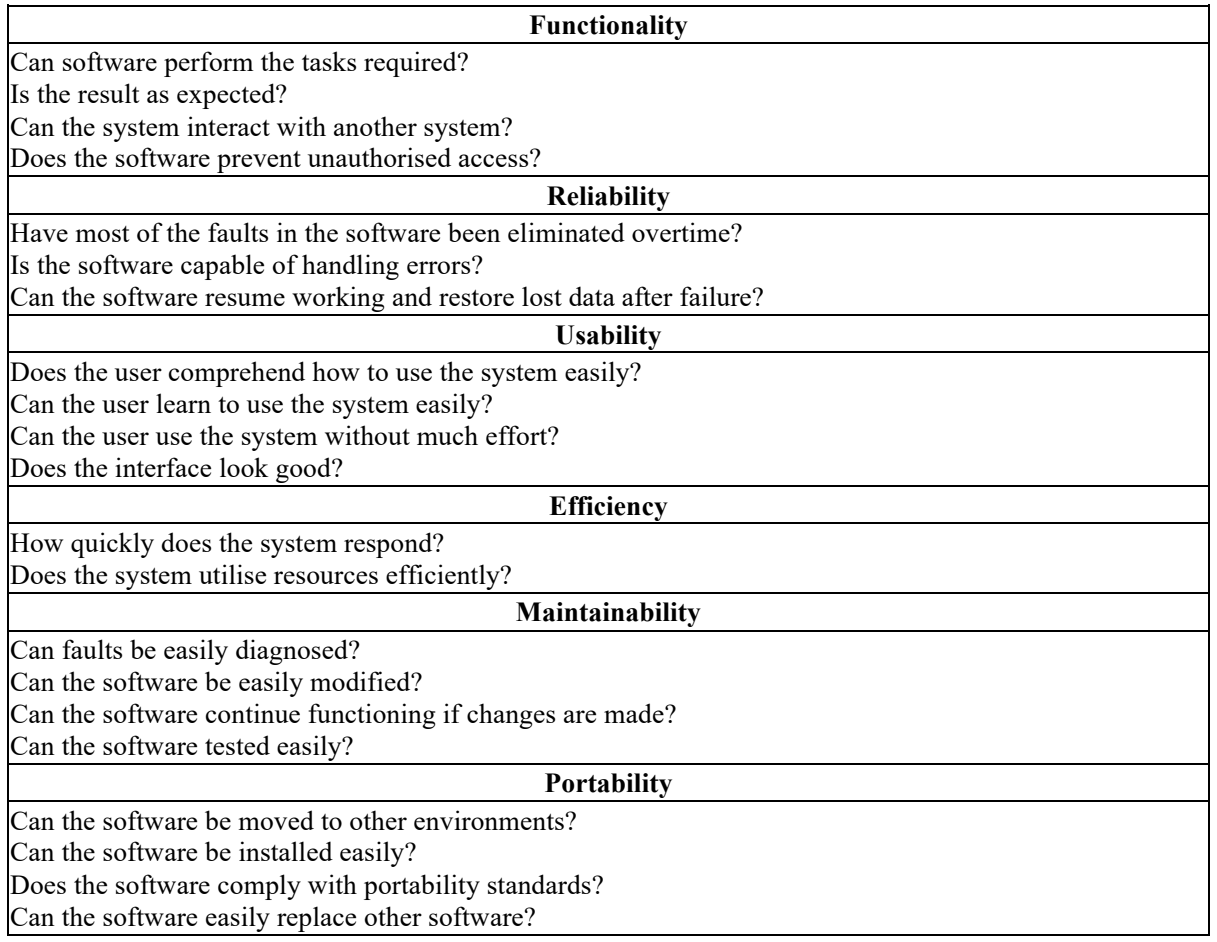


Many educators have shown significant interest in the pedagogical evaluation multimedia systems, that is, in course design issues and how to promote good learning. As a multimedia based instructional evaluation [13], it breaks into several components, as can be seen in Fig. 3 with break into some questions in Table 2.

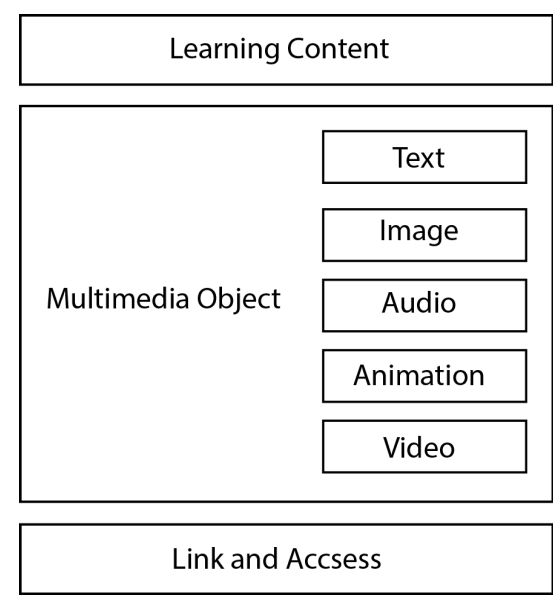

Fig. 3. Components of multimedia evaluation

Table 2. Questions use for multimedia based instructional evaluation

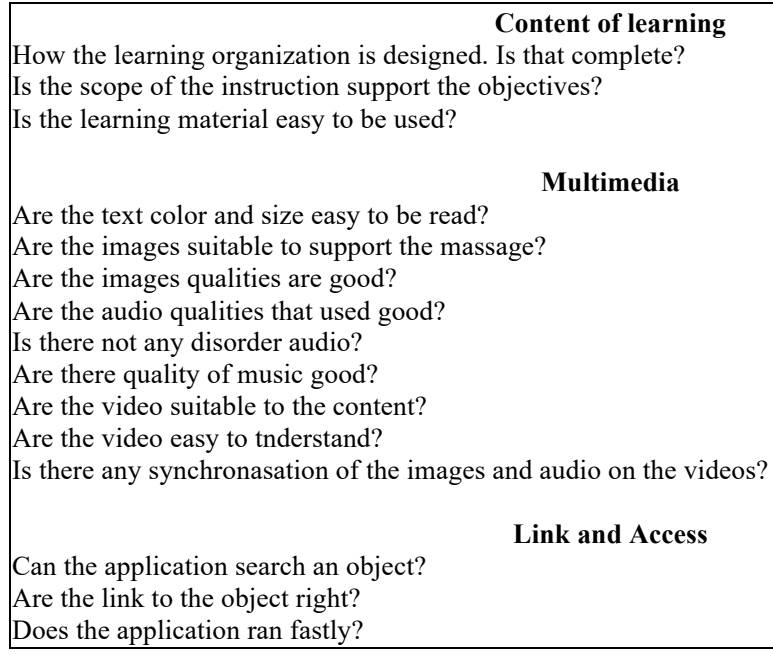

\section{Multimedia}

Are the images suitable to support the massage?

Are the images qualities are good?

Are the audio qualities that used good?

Is there not any disorder audio?

Are there quality of music good?

Are the video suitable to the content?

Are the video easy to tnderstand?

Is there any synchronasation of the images and audio on the videos?

Can the application search an object?

Link and Access

Are the link to the object right?

Does the application ran fastly?

\section{$3 \quad$ Result and Discussion}

Discussion the result of research falls into describing analyze, design, and develop. The implement and evaluate phases were not conducted in this research. The evaluation realized as testing in the develop phase. 


\subsection{Analyze}

In order to develop mobile "Stop Drugs Tutorial" application, the first step was Analyze that focusing on objectives of the development, audiences, content and infrastructure. The objectives of this phase was getting the information that was needed by government, educators and young people in running the mobile application, production equipment and human resources to develop the product. Equipment that was used to produce mobile

Stop Drugs Tutorial' was already available, that was a desktop computer with 4 GB of RAM, $250 \mathrm{~GB}$ hard drive and a mobile phone with Android operating system. The system software was Windows 7 Professional with the authoring tool Adobe Flash Professional CC. Adobe Flash is a visual object-oriented programming tool and can be used to develop interactive multimedia application [14].

Human resources necessary in creating mobile application consisted of author, illustrator, animator, video editor, multimedia programmer and multimedia designer. Based on the information on the research should include few items [15]-[16]:

- Categories of font design, history, characteristics and usage, text and background colors in accordance with the theory. Knowledge of graphic design principles is necessary to built the communicative and aesthetic message

- Animated mobile game with score

- Writing code or programming the way how to input data, mathematics operations, feedback, and scoring

- Multimedia objects i.e, symbol of movie clip, a tool of animation and interactive buttons

- File format that was piblished were SWF and APK [17]

- Publishing to Google Play in order that mobile game could be download by teachers, children, and parents.

\subsection{Design}

The next step was developing a navigation structure and storyboard of the mobile application reaching the objective of developing the application. Scene 1 was title page that continued with the Scene 2 containing table of content. The Scene 3 contained 7 topics and Scene 4 was the end of the application. At the scenes, user could either play again or exit. Fig. 4 shows the navigation structure of the application. 


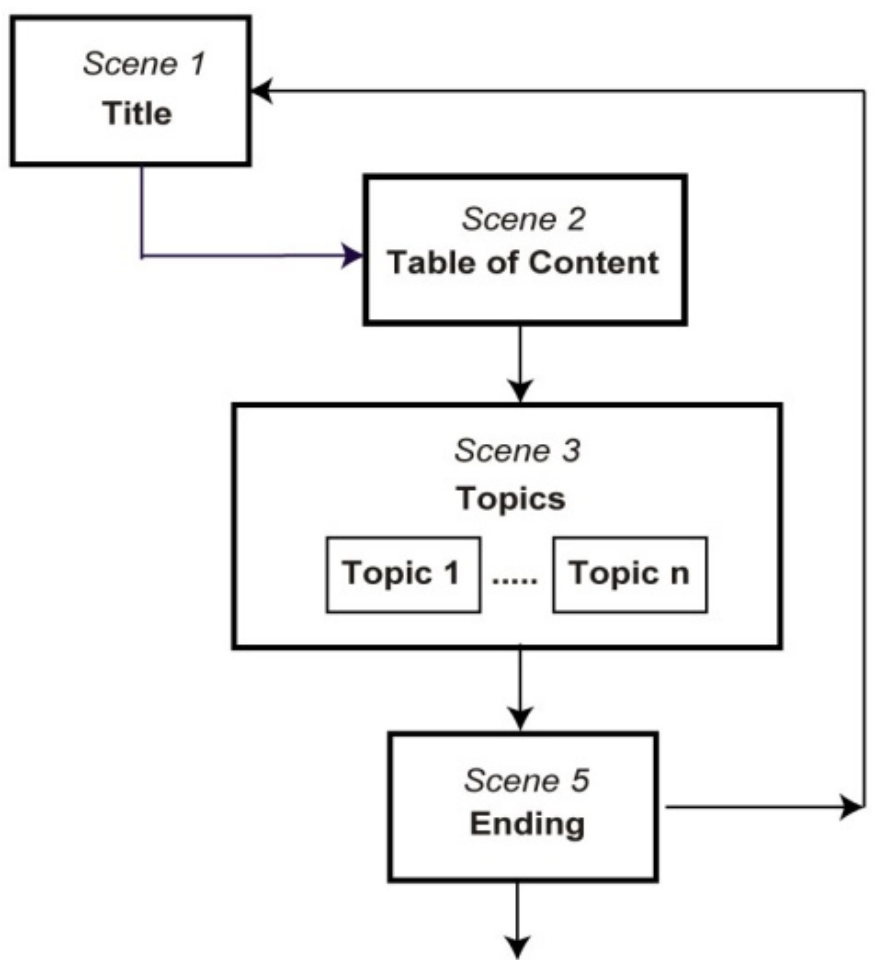

Fig. 4. Navigation structure of stop drugs tutorial

Designing the tutorial was required, so that the learning process became more effective and efficient. There were several topics of stop drugs tutorial. The learning material was about numbers of topics. There were 7 topics:

- Overview

- Category of Drugs

- Drugs Effect

- Detection of Drugs Addiction

- Role of Society

- Aspect of Law

- Rehabilitation

Every topic was provided with images that could be interested and made clear information.

\subsection{Develop}

Collecting of materials could be done in parallel with the stages of production. In this stage the materials such as images, animations, audio, video and other products were collected to be used in the next stage. Production stage was the stage where the 
entire multimedia object was created, and making application based on the storyboard and the navigation structure. Because the mobile game had a lot of interactivity and complexity, it was necessary to use ActionScript 3 programming which was the part of the Adobe Flash authoring [14].

Adobe Flash is a multimedia authoring originally acquired by Macromedia and currently developed and distributed by Adobe Systems. Since its introduction in 1996, Flash has become a popular method for adding animation and interactivity to web pages. Flash is commonly used to create animation, advertisements, and various web page Flash components, to integrate video into web pages, and more recently, to develop rich Internet applications [18]. Flash can manipulate vector and raster graphics, and supports bidirectional streaming of audio and video. It contains a scripting language called ActionScript. The Adobe Flash Professional CC was used to create content applications, i.e. games, presentations, content for mobile phones and other embedded devices. Fig. 5 shows the several displays the application on smartphone.
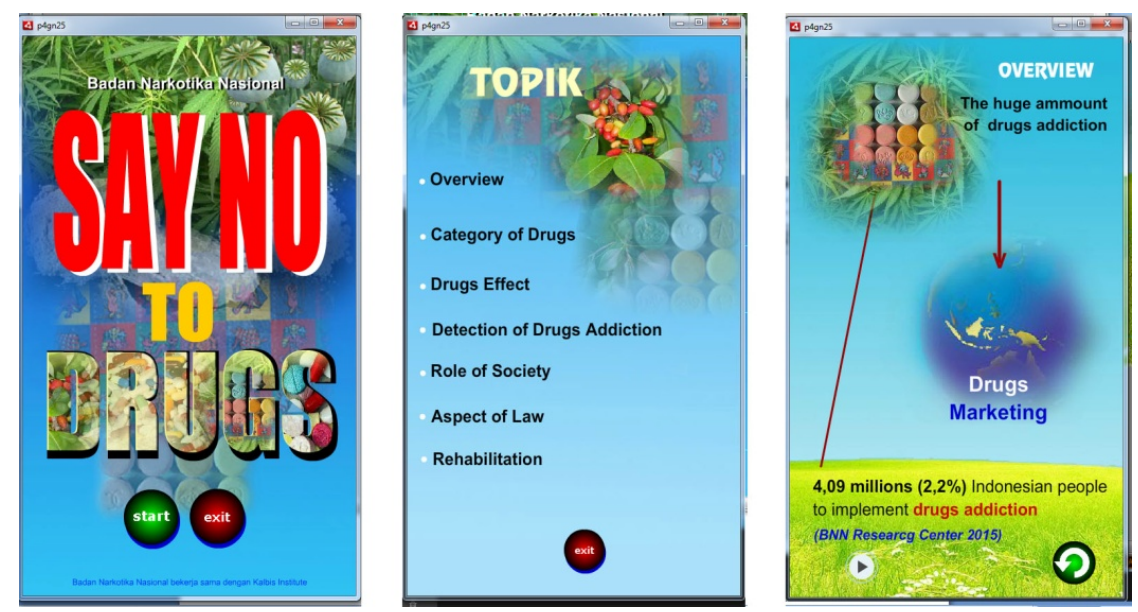

Fig. 5. Several displays of mobile multimedia stop drugs tutorial

\subsection{Testing}

Evaluation of mobile multimedia stop drugs tutorial was done by experts who had sufficient competence in the field of education, visual communication design, and information technology, conducted during the production process was almost complete. The experts found that many things should be improved and revised. Based on the comments that were given by the experts, the researchers decided the solutions as can be seen Table 3 . 
Table 3. Comment of reviewers and solution to improve mobile application

\begin{tabular}{|c|c|}
\hline Noted by reviewers & Solution \\
\hline \multicolumn{2}{|c|}{ Content of learning } \\
\hline $\begin{array}{l}\text { - The learning organization is not complete } \\
\text { - The scope of the instruction support the objectives } \\
\text { - The learning material is easy to be understood }\end{array}$ & $\begin{array}{l}\text { - The learning material can be completed with new } \\
\text { resources. }\end{array}$ \\
\hline \multicolumn{2}{|l|}{ Multimedia } \\
\hline $\begin{array}{l}\text { - Some of the image do not match with young style } \\
\text { - The is not any music in the application } \\
\text { - There is not any video in the application }\end{array}$ & $\begin{array}{l}\text { - Make special images for this application, not just } \\
\text { use the existing one } \\
\text { - Music can be added to the application } \\
\text { - Video will be added in the future research }\end{array}$ \\
\hline \multicolumn{2}{|c|}{ Link and Access } \\
\hline - There is no searching tool in the application & $\begin{array}{l}\text { - The application cannot search an object. It will be } \\
\text { covered in the future research }\end{array}$ \\
\hline \multicolumn{2}{|c|}{ Functionality } \\
\hline $\begin{array}{l}\text { - The result is as the exspectation } \\
\text { - There ia not interaction with other system such as } \\
\text { database. } \\
\text { - The software does not prevent unauthorised }\end{array}$ & $\begin{array}{l}\text { - The application does not design to interact with } \\
\text { other system, and it is good to interact with another } \\
\text { system in the fitire reseach } \\
\text { - The application has not to prevent unauthorized } \\
\text { access, it is an information for all users }\end{array}$ \\
\hline \multicolumn{2}{|c|}{ Reliability } \\
\hline $\begin{array}{l}\text { - It is not sure that most of the faults in the software } \\
\text { been eliminated overtime. } \\
\text { - It is not sure that the application can handling } \\
\text { errors. } \\
\text { - It is not sure that the application can restore lost } \\
\text { data after failure. }\end{array}$ & $\begin{array}{l}\text { - The application is not designed to handle the fault } \\
\text { - The application is not designed to handle error } \\
\text { - The software is not designed restore the lost data } \\
\text { after failure }\end{array}$ \\
\hline \multicolumn{2}{|c|}{ Usability } \\
\hline $\begin{array}{l}\text { - The user comprehend how to use the system easily. } \\
\text { - The user can learn to use the system easily. } \\
\text { - The user use the system without much effort. } \\
\text { - The interface does not look good. }\end{array}$ & - The interface can be improve to be better \\
\hline \multicolumn{2}{|c|}{ Efficiency } \\
\hline $\begin{array}{l}\text { - The application can respond quickly } \\
\text { - Does the system utilise resources efficientl. }\end{array}$ & - The system cannot utilize resources efficiently \\
\hline \multicolumn{2}{|c|}{ Maintainability } \\
\hline $\begin{array}{l}\text { - There is not any sign that identify a fault } \\
\text { - It is not sure that the application can be easily } \\
\text { modified. } \\
\text { - It is not sure that the application can continue } \\
\text { functioning if changes are made? }\end{array}$ & $\begin{array}{l}\text { - The software should be improve to identify fault in } \\
\text { the future research } \\
\text { - The software cannot be modified easily bacause it } \\
\text { needed a multimedia good programmer } \\
\text { - The software cannot continue functioning if } \\
\text { changes are made }\end{array}$ \\
\hline \multicolumn{2}{|c|}{ Portability } \\
\hline $\begin{array}{l}\text { - The software cannot be installed on Iphone. } \\
\text { - The software can be installed easily } \\
\text { - It is not sure that the application easily replace } \\
\text { other software? }\end{array}$ & $\begin{array}{l}\text { - The software can be used on Android mobile device } \\
\text { - There is not new version to replace the software }\end{array}$ \\
\hline
\end{tabular}



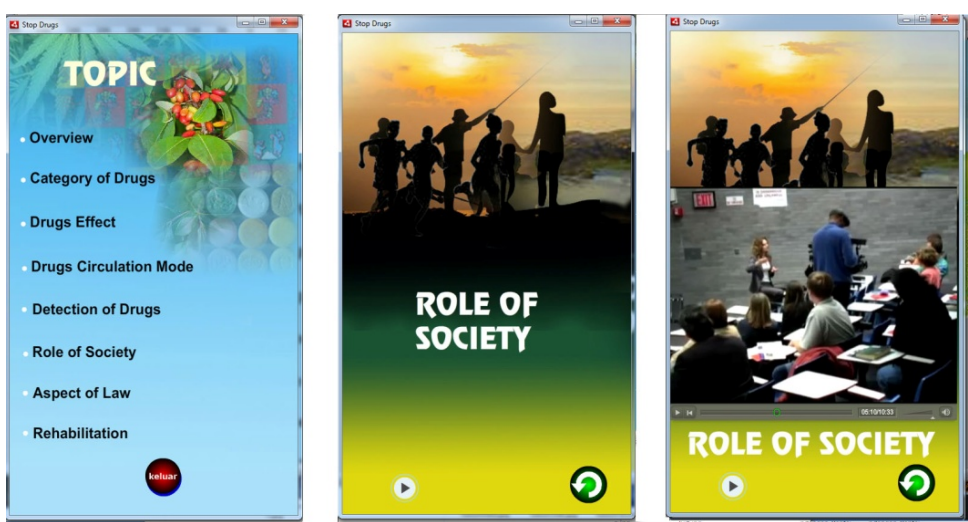

Fig. 6. Topic "Drugs Circulation Mode" was added (left), "Role of Society" before it had been changed and a video about parents discussion on drug use (right) in its display [19]

Based on the comments and suggestions that were given by the education, visual communication design, and information technology experts, researchers made improvement of the application. The learning material had been added with topic of Drugs Circullation and the application was provided with audio and video. It was done as can be seen in Fig. 6. After the mobile application had been revised, the next step was uploading APK format file of "Stop Drugs Tutorial" application to Google Play.

\subsection{Limitation of Research}

The research of developing mobile "Stop Drugs Tutorial" application includes 5 stages are not fully implemented. The Implement and Evaluate phases are not conducted. Evaluation just has been conducted for the testing during the Develop step. This study is limited only from first to third phase, in accordance with the needs of preparing to the next phases that can be accessed by everyone on mobile phone.

\section{Conclusion}

Developing of mobile multimedia was presented through this paper, and the description of mobile multimedia development is very important in this study because evaluation cannot be conducted without the development. There are two kinds of evaluation methods, which the one is according to educationalists and the other is according to software developers. The evaluation of mobile multimedia application uses combination of multimedia evaluation that was used by educationalists, and ISO 9126 that was used by software developers. The research findings showed that mobile multimedia stop drugs tutorial application could be used with minor revision.

Future research should be conducted to improve this mobile application. The future research had bettter be completed with videos, searching and interaction with other systems, and should be done including Implement and Evaluation phase. 


\section{$5 \quad$ Acknowledgement}

This paper was supported by Institut Teknologi dan Bisnis Kalbis in collaboration with National Narcotics Board Republic of Indonesia.

\section{References}

[1] Fischer, G. "Intelligent Systems/Tools In Training And Life-Long Learning", International Journal of Continuing Engineering Education and Life-Long Learning, [Online]. Accesed on September $2016 . \quad$ Available: http://citeseerx.ist.psu.edu/viewdoc/download?doi=10.1.1.39.6714\&rep=rep1\&type=pdf

[2] Vaughan, Tay. (2006). Multimedia Making It Work. Yogyakarta: Andi Publisher, pp. 234246.

[3] Medic8. Young People and addictions - Drug Addiction, [Online]. Accesed on May 11, 2016.Available:http://www.medic8.com/drug-addiction/young-people-and-addictions.html

[4] Powel. M. A. Comprehensive Analysis of the Drug-Crime Relationship. Southern Illinois University Carbondale, [Online]. Accesed on February 27, 2012 Available: http://opensiuc.lib.siu.edu/cgi/viewcontent.cgi?article=1059\&context=gs_rp

[5] hemul, H. T. The Impacts of Drugs on Young Generation of Bangladesh, [Online]. Accesed on August 16, 2016. Available: https://www.modernghana.com/news/211261/theimpacts-of-drugs-on-young-generation-of-bangladesh.html\#

[6] Bartoszewicki, M. Designing and Building an Interactive eBook, [Online]. Accesed on February 6, 2014. Available: http://www.aptaracorp.com/sites/default/files/designing-andbuilding-interactive-ebook.pdf.

[7] Johansson, D and Anderson, K. "Mobile e-Services: State of the Art, Focus Areas, and Future directions", Internatiomal Journal of E-Services and Mobile Applications. Vol. 7, No. 2, April-June 2015, [Online]. Accesed on November 4, 2015. Available: http://ltu.diva-portal.org/smash/get/diva2:986857/FULLTEXT01.pdf. https://doi.org/10.40 18/ijesma.2015040101

[8] Taylor, L et al. (2007). Educational Instructional Design Theories and Models. Place their and Simulation, p. 3, [Online]. Accesed on April 3, 2009. Available: http://www.siaa.asn.au/get/2396672209.pdf.

[9] Norbert M. et al. (2017). Instructional Design for Learning: Theoretical Foundations. Sense Publishers, Rotterdam, p. 6.

[10] Aldoobie, N. "ADDIE Model”, American International Journal of Contemporary Research, Vol. 5, No. 6, December 2015, pp. 1-6, [Online]. Accesed on August 15, 2016.Available: http://www.aijcrnet.com/journals/Vol_5_No_6_December_2015/10.pdf. https://doi.org/10. 14742/ajet. 1247

[11] Neo, M, Neo, T and Xiao-Lian, G. T. "A constructivist approach to learning an interactive multimedia course: Malaysian students' perspectives”, Australasian Journal of Educational Technology, [Online]. Accesed on December 5, 2015. Available: https://ajet.org.au/index.php/AJET/article/viewFile/1247/619.

[12] Chua, B. B \& L.E. Dyson. Applying the ISO 9126 model to the evaluation of an elearning system. Sydney: Faculty of Information Technology, University of Technology, (2004), [Online]. Accesed on January 21, 2011. Available: http://www.ascilite.org.au/conferences/perth04/procs/chua.html. 
[13] Sutopo, H. "Pengembangan model pembelajaran pembuatan aplikasi multimedia khususnya puzzle game pada mata kuliah multimedia," Ph.D. dissertation, Prodi Teknologi Pendidikan, Universitas Negeri Jakarta, Jakarta, Indonesia, 2009. https://doi.org/10.21009/ 1.02210

[14] Ypenburg, D. (2009). ActionScript 3.0: Learn ActionScript the Quick and Easy Way! Berkeley, CA: Peachpit Press, pp. xiii-xiv.

[15] D. Davis, F. D. "User acceptance of Information Technology: system characteristics, user perceptions and behavorial impacts", International Journal of Man-Machine Studies, Vol. 38, No 3, March 1993, [Online]. Accesed June 2, 2014. Available: https://dl.acm.org/citation.cfm?id=160021. https://doi.org/10.1006/imms.1993.1022

[16] Sihombing, D. (2002). Tipografi dalam Desain Grafis. Gramedia Pustaka Utama, Jakarta, pp. 3-40.

[17] Pandey, G and Diksha. "Android Mobile Application Build on Eclipse" in the International Journal of Scientific and Research Publications, Volume 4, Issue 2, February 2014, [Online]. Accesed on October 13, 2014. Available: http://www.ijsrp.org/research-paper0214/ijsrp-p26114.pdf.

[18] Franklin, D \& J. Makar. (2002). Macromedia Flash MX ActionScripting Advanced Training from the Source. Macromedia Press, p. 1.

[19] Nida, W. (2009). Parents discussion on drug use and addiction with Dr. Volkow NIDA. [Youtube], https://www.youtube.com/watch?v=2jp_wROPEY4. Diakses 4 January 2018.

\section{Authors}

Hadi Sutopo is senior member of International Institute of Electrical and Electronics Engineers (IEEE) in 2017, senior member of International Association of Computer Science and Information Technology (IACSIT), and member of Association for Educational Communications and Technology (AECT). He is Dean of Faculty of Creative Industry Kalbis Institute, Indonesia. He has been authoring Multimedia Programming with ActionScript 3.0 that had been published in May 2018. He has also authored many books on multimedia, information technology and educational technology. Many articles in journals and proceedings were published indexed by Scopus. His current research focuses on multimedia, computer graphics, and various aspects of educational technology.

Ridha Sefina Samosir is member of Association of Information Systems (AIS). She is Head of Information System Department, Faculty of Creative Industry Kalbis Institute, Indonesia. She has written many articles in journals and proceedings. Her research interests are computer graphics, images progessing and big data.

Jellend Gate is member of Association of Information Systems (AIS). He is a lecture at Information System Department, Faculty of Creative Industry Kalbis Institute, Indonesia. He has written many articles in journals and proceedings that were published indexed by Scopus. His research interests are bio informatics, image processing and mobile technology.

Article submitted 2018-08-28. Resubmitted 2019-02-06. Final acceptance 2019-03-31. Final version published as submitted by the authors 